Article

\title{
Phosphorus Fertilizer Rate, Soil P Availability, and Long-Term Growth Response in a Loblolly Pine Plantation on a Weathered Ultisol
}

\author{
D. Andrew Scott ${ }^{1, *}$ and Christine M. Bliss ${ }^{2}$ \\ 1 Southern Research Station, USDA Forest Service, P.O. Box 1927, Normal, AL 35762, USA \\ 2 North Florida Research and Education Center, University of Florida, 155 Research Road Quincy, \\ FL 32351, USA; E-Mail: cbliss@ufl.edu \\ * Author to whom correspondence should be addressed; E-Mail: andyscott@fs.fed.us; \\ Tel.: +1-256-372-4540; Fax: +1-256-372-8404.
}

Received: 29 August 2012; in revised form: 7 November 2012 / Accepted: 14 November 2012 / Published: 22 November 2012

\begin{abstract}
Phosphorus is widely deficient throughout the southern pine region of the United States. Growth responses to $\mathrm{P}$ fertilization are generally long-lasting in a wide range of soil types, but little is known about fertilization rates and long-term $\mathrm{P}$ cycling and availability. In 1982, exceptionally high $\mathrm{P}$ fertilization rates $\left(0,81,162\right.$, and $\left.324 \mathrm{~kg} \mathrm{P} \mathrm{ha}^{-1}\right)$ were applied to a loamy Ultisol in central Louisiana, USA. We measured vegetation responses at age 27 years and sequentially extracted soil $\mathrm{P}$ to $1 \mathrm{~m}$ to elucidate potential $\mathrm{P}$ availability into the next rotation. Loblolly pine responded well to the lowest fertilization rate; total biomass was $39 \%$ greater in the fertilized plots compared to the unfertilized plots, but higher fertilization rates had no effect, presumably due to induced N-limitations. What little fertilizer $\mathrm{P}$ was found in the soils was in the moderately labile $\mathrm{NaOH}$ fraction in the surface $20 \mathrm{~cm}$, and may be slowly available to the next pine rotation. Normal rates of $\mathrm{P}$ fertilizer will maintain elevated available $\mathrm{P}$ well into a second rotation in loamy Pleisteocene Ultisols of the western Gulf Coastal Plain. Exceptionally high rates were not effective at increasing potentially available $\mathrm{P}$ beyond normal rates.
\end{abstract}

Keywords: loblolly pine; phosphorus fertilization; phosphorus fractionation 


\section{Introduction}

The looming global $\mathrm{P}$ shortage [1] places a premium on understanding the most efficient use of $\mathrm{P}$ fertilizer to maintain productivity without squandering this vital resource for future food and fiber needs. Across much of the subtropics, highly weathered soils are P deficient due to inherently low mineral $\mathrm{P}$ in the parent material, the soil's advanced stage of weathering, and the tendency of orthophosphate to adsorb on hydrous metal oxides or become occluded in the secondary mineral structure. Previous research in the Atlantic Coastal Plain of the United States resulted in guidelines to help determine $\mathrm{P}$ deficiency [2,3], and it has been widely reported that many lower and upper Coastal Plain soils are $\mathrm{P}$ deficient and respond to $\mathrm{P}$ fertilization at establishment [4]. In the western Gulf Coastal Plain, soils developed from Pliocene deposits known as the Citronelle and related formations are widely known to be deficient [4]. Pleistocene-age terraces may not be as broadly deficient as Citronelle terraces but frequently respond to $\mathrm{P}$ fertilizer both at establishment and again at midrotation if accompanied by $\mathrm{N}$ additions [5].

Almost 6 million ha of southern pine forests have been fertilized with P since 1969 and about 80,000 ha year $^{-1}$ are currently fertilized [6]. Intensive harvesting may reduce productivity on marginally $\mathrm{P}$-sufficient soils $[7,8]$ and require $\mathrm{P}$ fertilization to maintain site productivity. While research has shown that $\mathrm{P}$ availability is enhanced for decades following fertilization [9], little is known about the influence of initial $P$ fertilizer rate on long-term $P$ fate and availability in forest soils.

Long-term fertilizer fate and growth response are determined not only by the initial inherent deficiency and rate applied, but also the availability of native and fertilizer P. Sandy soils in the Atlantic coast flatwoods retain relatively little fertilizer $\mathrm{P}$ in the surface soil [10,11]. Comparatively, in weathered loamy or finer textured soils, sorption on $\mathrm{Fe}$ and $\mathrm{Al}$ oxides and amorphous $\mathrm{Fe}$ and $\mathrm{Al}$ limits leaching through the profile [10]. Therefore, $\mathrm{P}$ fertilization is considered to be a site capacity-improving practice in most soils, and growth responses are of the Type II form [12]. Growth responses to $\mathrm{P}$ fertilization on medium or fine-textured, weathered soils may last over 50 years [9] and may be evident in a second rotation following harvest $[13,14]$. This long-term availability has been determined in Atlantic Coastal Plain Ultisols [13,15], New Zealand Ultisols [13], Australian Ultisols [9,14,16], Swedish Spodosols [17] and to some degree in Piedmont Ultisols [18] but long-term availability of fertilizer P in the highly weathered, Fe and Al-rich upland Alfisols and Ultisols of the western Gulf Coastal Plain has not been documented. In addition, little data is available to determine how long-term $P$ availability relates to initial fertilizer rate.

Phosphorus fertilization rates vary little within forested systems and are similar to annual rates applied to agricultural systems. Most forestry applications range from 28 to $56 \mathrm{~kg} \mathrm{ha}^{-1} \mathrm{P}$, but rates of 128 to $674 \mathrm{~kg} \mathrm{P} \mathrm{ha}^{-1}$ have been applied [18-20]. Tiarks [20] estimated that $162 \mathrm{~kg} \mathrm{P}^{-1}$ would be required for optimal loblolly pine (Pinus taeda L.) growth on a western Gulf upland soil based on a $\mathrm{P}$ isotherm experiment with seedlings. Even higher $\mathrm{P}$ fertilization rates are commonly suggested for soil restoration projects [21], especially when sites may not be revisited following initial restoration and when the soils have high $\mathrm{P}$ sorption or precipitation capacities. For example, $1000 \mathrm{~kg} \mathrm{P}^{-1}$ may be needed to overcome the $\mathrm{P}$ sorption capacity of coal-combustion waste materials and promote vegetation growth [22]. While high $\mathrm{P}$ fertilization rates may be necessary to overcome the $\mathrm{P}$ sorption capacity and increase available $\mathrm{P}$ levels to optimal levels, high $\mathrm{P}$ fertilization rates are also associated 
with increased P loss. Accordingly, the objectives of this study were to determine the long-term fertilizer $\mathrm{P}$ fate applied at exceptionally high rates and to fractionate soil $\mathrm{P}$ to elucidate potential $\mathrm{P}$ availability for the next pine rotation.

\section{Materials and Methods}

\subsection{Study Location and Establishment}

The study was conducted on the Longleaf Tract of the Palustris Experimental Forest in central Louisiana $\left(31.008^{\circ} \mathrm{N}, 92.616^{\circ} \mathrm{W}\right)[23,24]$. Prior to study establishment, vegetation was native grasses with scattered small hardwoods. The site was plowed in 1980 and disked three times in 1981 to reduce grass competition. The soil is a Beauregard silt loam (fine-silty, siliceous, superactive, thermic Plinthaquic Paleudult), which is very common to central Louisiana [25], and formed from loamy Pleistocene fluviomarine deposits. The study was double-planted in January-February of 1982 with 1-0 bare-root loblolly pine from a single half-sib family on a $2 \mathrm{~m} \times 3 \mathrm{~m}$ spacing with 15 rows of 11 planting spots per 0.1 -ha $(22 \mathrm{~m} \times 45 \mathrm{~m})$ plot. The seedlings were reduced to one live seedling per planting spot during the winter of 1982-1983. Nitrogen was applied as urea (46-0-0) to all plots (40 $\mathrm{kg} \mathrm{N} \mathrm{ha}^{-1}$ ) in April 1982. The study design was a completely randomized, split-plot design with three replications. The main plot factor included four $\mathrm{P}$ fertilizer rates $\left(0,81,162,324 \mathrm{~kg} \mathrm{P} \mathrm{ha}^{-1}\right)$ applied as triple superphosphate (TSP 0-45-0) in April 1982. Fertilizer rates for this soil were determined based on P isotherms [20], which indicated that $162 \mathrm{~kg} \mathrm{P} \mathrm{ha}{ }^{-1}$ would be required to supply the optimal $\mathrm{P}$ in soil solution for loblolly pine seedlings. The split-plot treatments consisted of three inter-row, direct-seeded biomass production treatments. Briefly, 50 loblolly pine seeds were direct-seeded in a grid pattern in the inter-row space between the planted seedlings in two of the three split-plots, while the third received no direct seeding. One of the two seeded treatments was harvested at age 4 years, while the other was never harvested. Details of these treatments have been described previously [24,26].

\subsection{Vegetation Response to Fertilization}

Total height and diameter at breast height $(1.3 \mathrm{~m})$ were measured on all live pine trees at age 27 years. The split-plot biomass treatments had no effect on main plot productivity and were not reported separately in this study. Total aboveground pine biomass (stem and crown) was estimated from allometric equations [27]. Understory vegetation taller than $1.37 \mathrm{~m}$ was tallied by total height and

number of stems per rootstock on three $90 \mathrm{~m}^{2}$ plots on each main treatment plot, and biomass was estimated from equations [28]. Understory plants shorter than $1.37 \mathrm{~m}$ were measured similarly, but on three $6 \mathrm{~m}^{2}$ plots per main treatment plot.

\subsection{Soil Sampling and Chemical Analysis}

Organic soil horizons (forest floor) were collected from three $0.0625 \mathrm{~m}^{2}$ quadrats per main treatment plot, dried at $70{ }^{\circ} \mathrm{C}$ to a constant weight and ground to pass a 1-mm mesh screen. The forest floor mass was adjusted for mineral content by dry ashing at $500{ }^{\circ} \mathrm{C}$ for $6 \mathrm{~h}$. The dry-ashed samples were taken up with $\mathrm{HCl}$ [13], and analyzed for P concentration colorimetrically [29]. 
Soil core samples were taken from the following depths: 0-10, 10-20, 20-30, 30-50, 50-75, and 75-100 cm, respectively. The samples were taken from two locations within each biomass split-plot (six subsamples per depth per main fertilizer treatment plot) using a tractor-mounted, 1.65 -cm diameter probe. The samples were oven-dried at $105{ }^{\circ} \mathrm{C}$ to a constant weight, and weighed for bulk density. Loose soil samples were taken with an auger from each of the three biomass split-plots (three subsamples per depth per main fertilizer treatment plot) at the same depths as bulk density. These samples were ground in a mill to pass a 2-mm sieve for analysis. All collected material was included in the sample, i.e., small rocks (iron concretions) and organic material (except roots, which were discarded). Because we included all material, rock content (which was nonexistent in the surface $50 \mathrm{~cm}$ and less than $5 \%$ up to $100 \mathrm{~cm}$ ) was not measured separately. For general site characterization purposes, one bulked soil sample for the entire site was created for each soil depth by combining approximately $10 \mathrm{~g}$ from each of the 36 individual loose samples per depth $(3$ subplots $\times 4$ main plots $\times 3$ replicates). Soil texture was determined by the hydrometer method [30]. Total $\mathrm{C}$ and $\mathrm{N}$ were determined by combustion with an Elementar CNS analyzer (Elementar Americas, NJ, USA). Soil pH was determined in a 1:1 soil:water paste.

Soil P fractions and Mehlich I-extractable P [31] were analyzed on all 216 samples (36 samples per depth $\times 6$ depths) according to a modified Tiessen and Moir [32] fractionation scheme using successive fractionations. Resin-extractable $\mathrm{P}$ was not determined because initial tests indicated that very little, if any, P could be extracted by this method in these soils, and any P normally found in these fractions would be included in the bicarbonate-extractable $\mathrm{P}$ fraction. Bicarbonate-extractable $\mathrm{P}$ (labile P) was extracted with $\mathrm{NaHCO}_{3}$ and fractionated into inorganic $\left(\mathrm{P}_{\mathrm{i}}\right)$ and organic $\left(\mathrm{P}_{\mathrm{o}}\right)$ fractions by first analyzing for orthophosphate and then dry ashing the evaporated extract and digesting with $\mathrm{HCl}$ and analyzing again for total $\mathrm{P}$ [33]. Organic $\mathrm{P}$ was considered to be the difference between total and inorganic P. Moderately labile $\mathrm{P}$ was extracted with $\mathrm{NaOH}$, and also separated into organic and orthophosphate fractions. Strongly held, non-labile P was extracted with $\mathrm{HCl}$. On a separate sample, total soil $\mathrm{P}$ was determined with a hot $\mathrm{H}_{2} \mathrm{SO}_{4}+\mathrm{H}_{2} \mathrm{O}_{2}$ digestion [32]. Residual $\mathrm{P}$ was calculated as the difference between total $\mathrm{P}$ and the sum of all other extractions. All extracts were analyzed colorimetrically by spectrophotometry [29].

\subsection{Hydrology Estimates}

To assess the potential for $\mathrm{P}$ runoff or leaching, we calculated the maximum quantity of water available for runoff or percolation by subtracting potential evapotranspiration (PET) [34], from precipitation [35]. Monthly temperature and precipitation data were obtained for the period 1982-2010 from a compilation of weather stations in central Louisiana [36]. No attempt was made to estimate actual evapotranspiration, as more detailed data were not available.

\subsection{Statistical Analysis}

Subplot means of tree and understory biomass, soil $\mathrm{P}$ fractions, and forest floor samples were analyzed as a split-plot design within a completely randomized design with 3 replicates using Proc Mixed [37]. Least-squares means were separated using Tukey adjusted pairwise comparisons at $p>0.05$. 


\section{Results}

\subsection{Soil and Stand Characteristics}

The somewhat poorly drained Beauregard soil was characteristic of the low P, Pleistocene-age terraces of the western Gulf Coastal Plain. The soil texture was silt loam to loam for entire profile sampled $(100 \mathrm{~cm})$, although slight clay increases were evident between the $\mathrm{A}$ and Bt horizons (approximately $20 \mathrm{~cm}$ ). The soil was moderately to strongly acidic $(\mathrm{pH} 4.73-5.10)$, and had low soil $\mathrm{C}$ and $\mathrm{N}$ content to a depth of $1 \mathrm{~m}\left(72.9\right.$ and $6.45 \mathrm{Mg} \mathrm{C}$ and $\mathrm{N} \mathrm{ha}{ }^{-1}$, respectively). Soil $\mathrm{C}$ and $\mathrm{N}$ concentrations in the surface $10 \mathrm{~cm}$ were also relatively low (16.91 and $0.99 \mathrm{mg} \mathrm{kg}^{-1}$, respectively) (Table 1). The site was flat, with less than 1\% slope, although the slope had a consistent southern aspect toward a small ( 1 ha) reservoir. Estimated PET ranged from 97 to $116 \mathrm{~cm}$ (averaging $104 \mathrm{~cm}$ ) and annual precipitation averaged $155 \mathrm{~cm}$, ranging from 113 to $195 \mathrm{~cm}$ (Figure 1). Potential annual water excess was almost always substantially higher than estimated PET; excess water averaged $51 \mathrm{~cm}$ and totaled $1378 \mathrm{~cm}$. During the first three years, excess water averaged over $70 \mathrm{~cm}$ due to higher than average rainfall.

Table 1. General soil characteristics of the study area, a loamy Ultisol in the West Gulf Coastal Plain of the United States. Bulk density means and standard deviations are from $n=72$ samples per depth.

\begin{tabular}{|c|c|c|c|c|c|c|}
\hline \multirow{2}{*}{ Depth } & \multirow{2}{*}{$\begin{array}{c}\text { Bulk density } \\
\left(\mathrm{Mg} \mathrm{m}^{-3}\right)\end{array}$} & Clay & Sand & \multirow{2}{*}{$\mathbf{p H}$} & $\mathbf{C}$ & $\mathbf{N}$ \\
\hline & & \multicolumn{2}{|c|}{$(\%)$} & & \multicolumn{2}{|c|}{$\left(\mathrm{mg} \mathrm{kg}^{-1}\right)$} \\
\hline $0-10$ & $1.27(0.10)$ & 9 & 33 & 5.04 & 16.91 & 0.99 \\
\hline $10-20$ & $1.46(0.08)$ & 11 & 31 & 5.02 & 11.53 & 0.60 \\
\hline $20-30$ & $1.54(0.09)$ & 17 & 33 & 4.75 & 6.07 & 0.44 \\
\hline $30-50$ & $1.53(0.11)$ & 22 & 25 & 4.76 & 3.16 & 0.45 \\
\hline $50-75$ & $1.61(0.07)$ & 25 & 29 & 4.73 & 2.34 & 0.32 \\
\hline $75-100$ & $1.70(0.08)$ & 21 & 29 & 5.10 & 1.44 & 0.23 \\
\hline
\end{tabular}

Figure 1. Potential evapotranspiration (PET), precipitation and excess water (PET-precipitation) in central Louisiana, USA from 1982 to 2008.

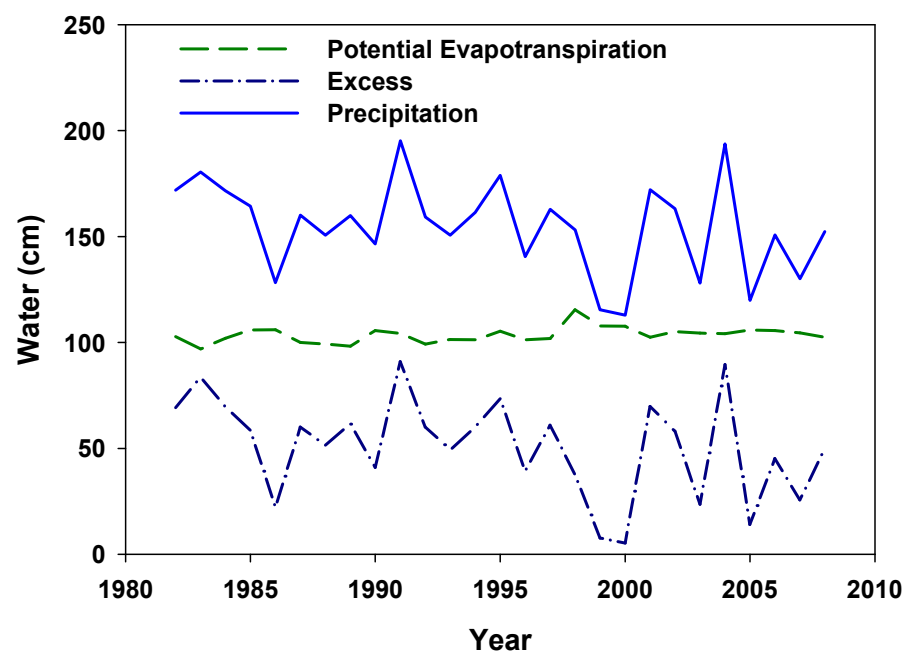




\subsection{Vegetative Response to Fertilization}

Planted loblolly pine height, dbh, and total aboveground biomass were all greater on the fertilized plots (Table 2), but were not different among the fertilizer rates. While pine biomass growth was influenced by the initial biomass seeding treatments (Table 2), the interaction between fertilization and seeding treatment was not significant. Fertilized pine trees were almost $3 \mathrm{~m}$ taller and had $2.7 \mathrm{~cm}$ greater diameters than unfertilized pine trees (Table 3). Stand density was $12 \%$ lower (161 trees ha ${ }^{-1}$ ) in the $162 \mathrm{~kg} \mathrm{P} \mathrm{ha}^{-1}$ treatment plots compared to the unfertilized plots, but density was similar among all other treatments. Aboveground pine biomass was 39\% greater in the fertilized plots compared to the unfertilized plots, and mean annual increment (MAI) was $3.3 \mathrm{Mg} \mathrm{ha}^{-1}$ year $^{-1}$ greater in fertilized plots. Non-planted vegetation biomass, mostly consisting of Chinese privet (Ligustrum sinense Lour.), wax myrtle (Morella cerifera (L.) Small), yaupon (Ilex vomitoria Aiton) and red maple (Acer rubrum L.) averaged about $2.3 \mathrm{Mg} \mathrm{ha}^{-1}$ and was similar among all the fertilizer treatments. More detailed stand dynamics were presented for this experiment at age 22 years [26].

Table 2. Probabilities of a greater $F$-value for mean tree stand characteristics of 27-year-old loblolly pine stands subjected to four $\mathrm{P}$ fertilization rates $(\mathrm{F})$, three direct-seeded interrow biomass energy cropping systems (CS), and their interaction (F X CS).

\begin{tabular}{cccccccc}
\hline Effect & Df & Height & Dbh & Density & Volume & Pine biomass $\begin{array}{c}\text { Other } \\
\text { vegetation } \\
\text { biomass }\end{array}$ \\
\hline F & 3 & 0.0016 & 0.0120 & 0.1884 & 0.0080 & 0.0074 & 1.76 \\
CS & 2 & 0.0625 & 0.7386 & 0.5707 & 0.0270 & 0.0271 & 0.55 \\
F X CS & 6 & 0.1245 & 0.7137 & 0.6123 & 0.2603 & 0.2516 & 1.69 \\
\hline
\end{tabular}

Table 3. Mean height, diameter, stand density and aboveground biomass of 27-year-old loblolly pine stands subjected to four phosphorus fertilization rates.

\begin{tabular}{ccccccc}
\hline Treatment & $\begin{array}{c}\text { Height } \\
(\mathbf{m})\end{array}$ & $\begin{array}{c}\text { Dbh } \\
(\mathbf{c m})\end{array}$ & $\begin{array}{c}\text { Density } \\
\left.\mathbf{T r e e s ~ h a}^{-\mathbf{1}}\right)\end{array}$ & $\begin{array}{c}\text { Pine biomass } \\
\left(\mathbf{M g ~ h a}^{-\mathbf{1}}\right)\end{array}$ & $\begin{array}{c}\text { Understory } \\
\text { biomass }\left(\mathbf{M g ~ h a}^{-\mathbf{1}}\right)\end{array}$ & $\begin{array}{c}\text { Forest floor } \\
\text { biomass }\left(\mathbf{M g ~ h a}^{-\mathbf{1}}\right)\end{array}$ \\
\hline Fertilization & & & & & & \\
0 & $22.0 \mathrm{~b}$ & $20.5 \mathrm{~b}$ & $1321 \mathrm{a}$ & $230 \mathrm{~b}$ & $3.1 \mathrm{a}$ & $14.4 \mathrm{a}$ \\
81 & $24.3 \mathrm{a}$ & $22.7 \mathrm{a}$ & $1235 \mathrm{ab}$ & $311 \mathrm{a}$ & $2.5 \mathrm{a}$ & $18.0 \mathrm{a}$ \\
162 & $25.5 \mathrm{a}$ & $23.7 \mathrm{a}$ & $1160 \mathrm{~b}$ & $318 \mathrm{a}$ & $2.2 \mathrm{a}$ & $17.5 \mathrm{a}$ \\
324 & $25.1 \mathrm{a}$ & $23.1 \mathrm{a}$ & $1259 \mathrm{ab}$ & $329 \mathrm{a}$ & $1.3 \mathrm{a}$ & $18.9 \mathrm{a}$ \\
\hline
\end{tabular}

\subsection{Phosphorus Availability and Pools}

Mehlich I extractable P was generally low for southern pine stands (less than $3-5 \mathrm{~kg} \mathrm{P} \mathrm{ha}^{-1}$ ) in the unfertilized plots, even in the surface $10 \mathrm{~cm}\left(1.93 \mathrm{~kg} \mathrm{P} \mathrm{ha}^{-1}\right.$ ) (Figure 2). Mehlich I extractable $\mathrm{P}$ was $67 \%$ greater in the surface $20 \mathrm{~cm}$ in the $81 \mathrm{~kg} \mathrm{P} \mathrm{ha}^{-1}$ fertilized plots as compared to the unfertilized plots while the plots fertilized at higher rates (162 and $324 \mathrm{~kg} \mathrm{P} \mathrm{ha}^{-1}$ ) had almost 3-fold more in the surface $20 \mathrm{~cm}$ compared to the unfertilized plots (Figure 2). No differences were found either between the two highest fertilization rates or among any rates at depths greater than $20 \mathrm{~cm}$ (Figure 2). 
Figure 2. Mehlich I extractable phosphorus in a loamy Ultisol in the western Gulf Coastal Plain of the United States 27 years after high rates of triple superphosphate fertilization.

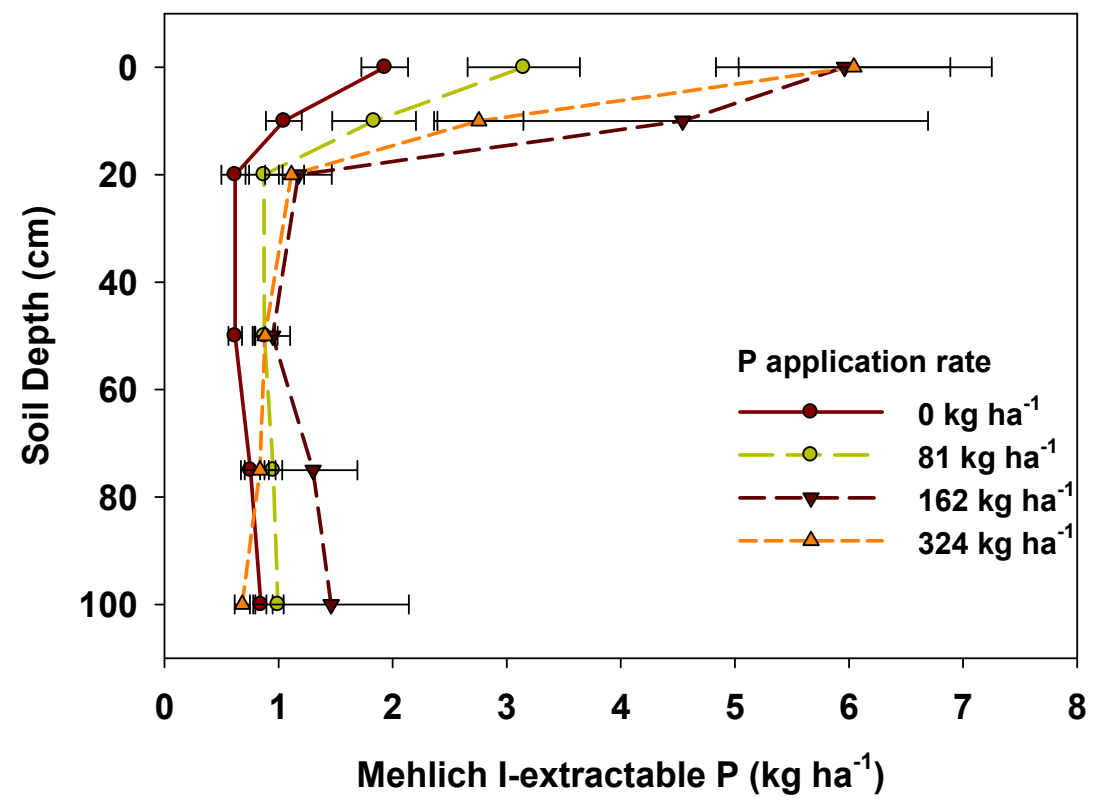

Soil $\mathrm{P}$ fractions varied by depth and fertilizer rate (Figure 3). About $77 \%$ of the $\mathrm{P}$ was held in the residual fraction, while about $20 \%$ was in the moderately labile fraction $(\mathrm{NaOH})$. Very little $\mathrm{P}$ was held in the labile inorganic fraction $\left(\mathrm{NaHCO}_{3}\right)$ (Figure 3A), but the amount extracted was higher in the fertilized soils in the surface $0-10$ and 10-20 cm depths. In the labile organic $\mathrm{NaHCO}_{3}$ pool, about $10 \mathrm{~kg} \mathrm{ha}^{-1}$ (9.0 in fertilized soils; 6.7 in unfertilized soils) was in the surface $10 \mathrm{~cm}$, and another $5 \mathrm{~kg} \mathrm{ha}^{-1}$ (6.4 in fertilized soils; 4.1 in unfertilized soils) was in the $10-20 \mathrm{~cm}$ depth (Figure $3 \mathrm{~B}$ ). Unfertilized soils had about $190 \mathrm{~kg} \mathrm{ha}^{-1} \mathrm{P}$ in the moderately labile $(\mathrm{NaOH})$ pool throughout the full $100 \mathrm{~cm}$, while fertilized soils had about $250 \mathrm{~kg} \mathrm{ha}^{-1}$ in this pool (Figure 3C,D), and contained significantly more $\mathrm{P}$ in the surface $20 \mathrm{~cm}$ than the unfertilized soils. The organic and inorganic fractions were approximately evenly divided in this pool (55\% was organic). The strongly held non-labile fraction $(\mathrm{HCl})$ had virtually no $\mathrm{P}$ (Figure $3 \mathrm{E}$ ), and neither it nor the residual $\mathrm{P}$ (Figure $3 \mathrm{~F}$ ) had significantly different pools among fertilizer rates.

Total $\mathrm{P}$ measured in the surface $1 \mathrm{~m}$ of soil (including the forest floor) ranged from 1122 to $1236 \mathrm{~kg} \mathrm{ha}^{-1}$ (Table 4), and averaged 1180 in the fertilized plots. Total $\mathrm{P}$ in the mineral soil to $1 \mathrm{~m}$ was not significantly different among the fertilized plots despite the four-fold difference in rate. Forest floor $\mathrm{P}$ was similar among all treatments and averaged $5.8 \mathrm{~kg} \mathrm{ha}^{-1}$. The surface mineral soil (upper $20 \mathrm{~cm}$ ) contained about $20 \%$ of the total mineral soil pool of P in the unfertilized plots, and about $24 \%$ of the mineral soil $\mathrm{P}$ in the fertilized plots. Total $\mathrm{P}$ was about $66.6 \mathrm{~kg} \mathrm{ha}^{-1}$ greater in the surface $20 \mathrm{~cm}$ in the 162 and $324 \mathrm{~kg} \mathrm{ha}^{-1}$ treatment plots compared to the unfertilized soils, but was not different among the fertilized soils. Total subsoil $\mathrm{P}$ was similar among all soils, as was total $\mathrm{P}$ to $1 \mathrm{~m}$ depth. Potentially available $\mathrm{P}$, which included all fractions except the $\mathrm{HCl}$ and $\mathrm{H}_{2} \mathrm{SO}_{4}$ extracts (strongly held, non-labile and residual fractions), ranged from about $216 \mathrm{~kg} \mathrm{ha}^{-1}$ in the unfertilized plots to an average of about $287 \mathrm{~kg} \mathrm{ha}^{-1}$ in the fertilized plots to a depth of $1 \mathrm{~m}$, suggesting that about $71 \mathrm{~kg} \mathrm{ha}^{-1}$ of fertilizer P was found in the potentially available fractions. Similar to total P, potentially available P 
was statistically different between the unfertilized and fertilized plots only in the surface soil, and no differences were found among the fertilized plots.

Figure 3. Phosphorus fractions in a loamy Ultisol in the western Gulf Coastal Plain of the United States 27 years after high rates of triple superphosphate fertilization. * Significant difference at $p<0.05$ at that soil depth. $\mathrm{P}_{\mathrm{i}}$ indicates inorganic form, while $\mathrm{P}_{\mathrm{o}}$ indicates organic form.
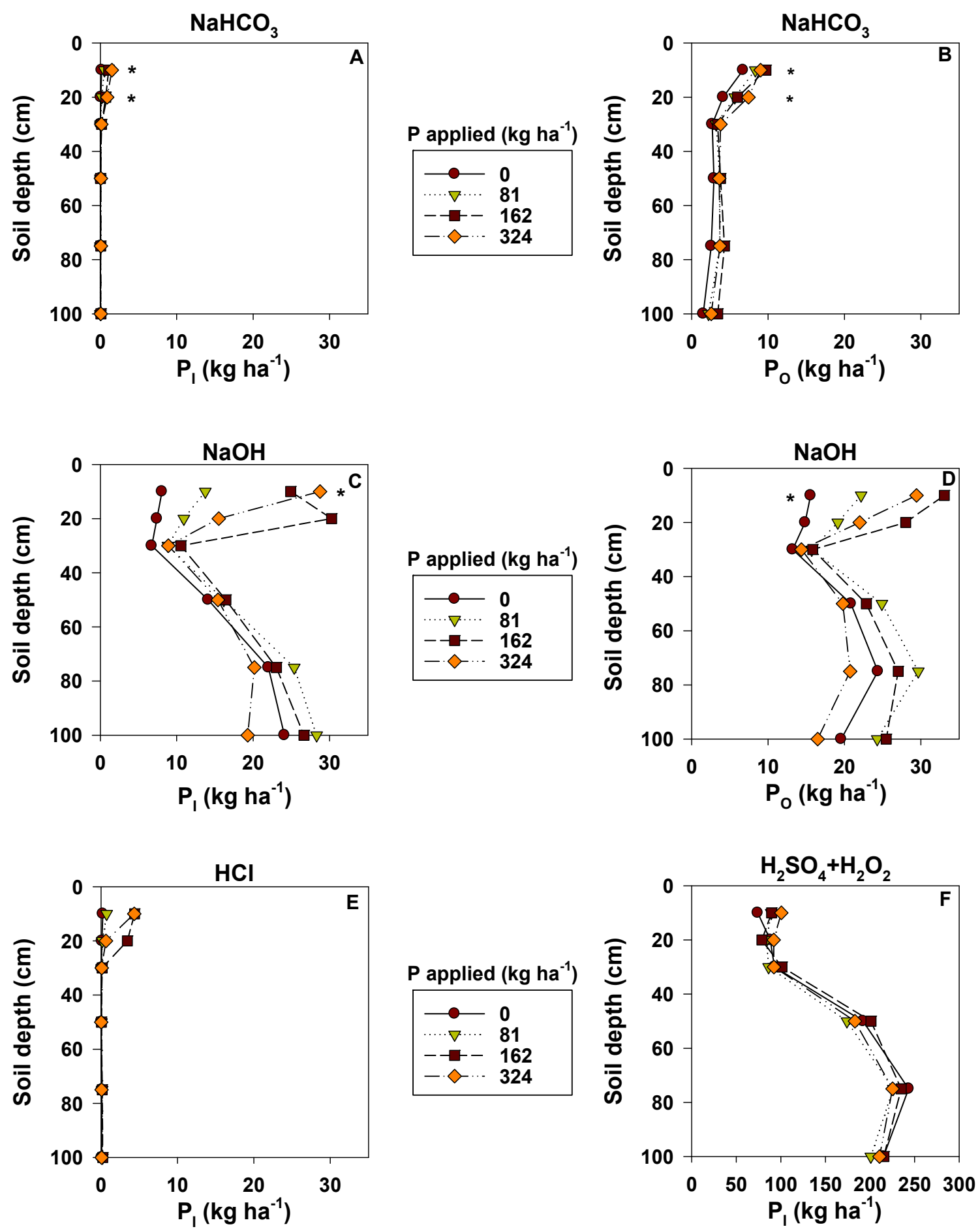
Table 4. Total and potentially available phosphorus $(\mathrm{P})$ recovered in the forest floor and soil to $1 \mathrm{~m}$ depth 27 years following fertilization at plantation establishment. Values are means for the whole-plot treatments with standard errors in parentheses. Means within a row followed by different letters are significantly different at $p<0.05$.

\begin{tabular}{lcrrr}
\hline Total P $\left(\mathbf{k g ~ h a}^{-\mathbf{1}}\right)$ & \multicolumn{5}{c}{ Fertilizer rate $\mathbf{( k g ~ h a} \mathbf{~}^{-\mathbf{1}} \mathbf{)}$} \\
\hline Soil Pool & 0 & 81 & 162 & \multicolumn{1}{c}{324} \\
Forest floor & $4.4(0.55) \mathrm{a}$ & $5.5(0.57) \mathrm{a}$ & $6.9(0.58) \mathrm{a}$ & $6.5(0.76) \mathrm{a}$ \\
Surface soil $(0-20 \mathrm{~cm})$ & $219.7(6.0) \mathrm{a}$ & $254.8(6.5) \mathrm{ab}$ & $292.0(34.3) \mathrm{b}$ & $312.2(22.6) \mathrm{b}$ \\
Subsoil $(20-100 \mathrm{~cm})$ & $898.4(26.7) \mathrm{a}$ & $874.2(32.6) \mathrm{a}$ & $936.8(97.4) \mathrm{a}$ & $849.7(38.2) \mathrm{a}$ \\
Total mineral soil $(0-100 \mathrm{~cm})$ & $1118.1(30.6) \mathrm{a}$ & $1129.1(36.2) \mathrm{a}$ & $1228.8(96.8) \mathrm{a}$ & $1162.0(56.6) \mathrm{a}$ \\
\hline Potentially available P & & & & \\
(kg ha $^{-1} \mathbf{)}$ & & & & \\
\hline Surface soil $(0-20 \mathrm{~cm})$ & $57.0(2.56) \mathrm{b}$ & $80.7(4.20) \mathrm{ab}$ & $126.1(18.16) \mathrm{a}$ & $118.4(11.24) \mathrm{a}$ \\
Subsoil $(20-100 \mathrm{~cm})$ & $154.6(7.82) \mathrm{a}$ & $186.0(9.16) \mathrm{a}$ & $183.1(22.0) \mathrm{a}$ & $143.0(12.70) \mathrm{a}$ \\
Total (forest floor + & & & & \\
mineral soil) & $215.9(9.05) \mathrm{a}$ & $272.2(12.44) \mathrm{a}$ & $316.2(34.06) \mathrm{a}$ & $272.3(16.51) \mathrm{a}$ \\
\hline
\end{tabular}

${ }^{1}$ Potentially available $\mathrm{P}$ included forest floor $\mathrm{P}, \mathrm{NaHCO}_{3}$ and $\mathrm{NaOH}$ extracts (inorganic and organic) but not $\mathrm{HCl}$ or $\mathrm{H}_{2} \mathrm{SO}_{4}$ fractions.

\section{Discussion}

\subsection{Vegetative Response}

While the soil was clearly P-deficient as evidenced by the sustained growth response to $\mathrm{P}$ fertilization, the trees and understory vegetation did not respond to the higher fertilizer rates as expected by Tiarks [20]. The fertilization rates were based on the soil solution P concentration required for pine seedlings to attain maximum growth in pots. The lack of a continued response to higher fertilization rates was probably due to a lack of other nutrients, especially $\mathrm{N}$. The $3.3 \mathrm{Mg} \mathrm{ha}^{-1}$ increase in MAI and $3 \mathrm{~m}$ increase in site index (base age 25) is similar to the $3.4 \mathrm{Mg} \mathrm{ha}^{-1}$ and $3 \mathrm{~m}$ increases in MAI and site index, respectively, reported for loblolly pine on highly deficient soils across the southeastern U.S. [38]. While some luxury P may have been taken up in the foliage of the trees fertilized with more than $81 \mathrm{~kg} \mathrm{ha}^{-1}$, it is not likely that much of the additional $\mathrm{P}$ was taken up by the vegetation. Unfortunately, the stand was harvested before foliage samples could be obtained to verify plant uptake. While the limited application of $\mathrm{N}\left(40 \mathrm{~kg} \mathrm{ha}^{-1}\right)$ at study establishment did provide some $\mathrm{N}$, tree demand did not likely exceed supply for $\mathrm{N}$ until closer to mid-rotation, at which point this stand was likely $\mathrm{N}$ deficient, especially on the P-fertilized plots [39].

\subsection{Fertilizer P Fate}

In P-deficient forest lands with low soil test $\mathrm{P}$, high $\mathrm{P}$ sorption capacities and high plant growth potential, the long-term leaching loss of fertilizer $\mathrm{P}$ is assumed to be low [40]. While the trees did respond to $\mathrm{P}$ application and plant uptake would account for some of the fertilizer $\mathrm{P}$, the lack of response in the higher $\mathrm{P}$ rate treatment plots implies that the $\mathrm{P}$ applied in excess of $81 \mathrm{~kg} \mathrm{ha}^{-1}$ was not 
taken up in the vegetation. Therefore, we expected to find much of the fertilizer $\mathrm{P}$ in the in the $\mathrm{NaOH}$-extractable, moderately labile $\mathrm{P}_{\mathrm{i}}$ and $\mathrm{P}_{\mathrm{o}}$ in the surface and upper subsoil.

Soil $\mathrm{P}$ did not accumulate in deeper horizons. The control plots had the second-highest mean soil $\mathrm{P}$ at deeper soil layers and the highest $\left(324 \mathrm{~kg} \mathrm{ha}^{-1}\right)$ fertilizer rate plots had the lowest $\mathrm{P}$ content in the 20-100 cm depth. Data from the P fractionation studies similarly indicate that $\mathrm{P}$ was not elevated in the weakly held, moderately labile fraction at deeper depths whereas this fraction constituted the bulk of the fertilizer P pool in the surface soil (Figure 2). Other studies with high rates of P loading have also found no increases in P below the surface depth [41,42], while Shoulders and Tiarks [43] did find elevated available $\mathrm{P}$ between 18 and $36 \mathrm{~cm}$ in a very similar soil 8 years after fertilization with $95 \mathrm{~kg} \mathrm{P} \mathrm{ha}^{-1}$.

While we cannot provide quantitative estimates of $\mathrm{P}$ uptake, our data suggests that $\mathrm{P}$ loss in the high rate plots may have been substantial. The $\mathrm{P}$ may have leached via preferential flow through voids or root pathways, as found in a clayey soil [44], but the site had few woody perennials prior to study establishment, limiting the number of root channels available for preferential flow. Conversely, P may have been lost due to lateral flow, either as surface runoff or along the boundary between the surface and subsoil horizons. Soluble fertilizer P is susceptible to runoff or lateral flow due to rainfall [45-47], especially directly after fertilizer application. The abundance of excess water in this study, especially during the first few years after planting (Figure 1), provides evidence that the water flow necessary for surface or subsurface runoff was adequate. Therefore, long-term surface and subsurface runoff of the $\mathrm{P}$ fertilizer was potentially one mechanism for P loss.

The fertilizer may have been lost very early in the study due to "incidental" [48,49] or "event-specific" [50] losses, which are generally overlooked due to the relative importance of soil P status and long-term fertilization of agricultural and pastoral lands toward determining soil P loss [51]. One nearby $(20 \mathrm{~km})$ weather station in Oakdale, Louisiana, reported over $250 \mathrm{~mm}$ of precipitation in April 1982, including one storm of over $120 \mathrm{~mm}$ of rain [36]. Given that the fertilizer was applied in April 1982 and that the surface soil permeability is only 1.5 to $5 \mathrm{~cm} \mathrm{~h}^{-1}$ [25], a storm of this magnitude may have caused much of the $\mathrm{P}$ loss. When event-specific losses occur, they can account for $50 \%-98 \%$ of the total $\mathrm{P}$ lost in surface and subsurface runoff [49], and under high rates of superphosphate application, reduced contact of the fertilizer with the mineral soil creates a situation whereby high intensity rainfall can easily transport the fertilizer P [49,52]. Situations like this essentially render the high soil $\mathrm{P}$ sorption capacity ineffective.

\subsection{P Availability}

Most of the fertilizer retained was contained in the weakly held, moderately labile pool, which roughly corresponds to the $\mathrm{P}$ chemisorbed onto the amorphous $\mathrm{Fe}$ and $\mathrm{Al}$ sesquioxides. While this fraction may not be labile over the span of a single growing season, it does interact with the soil solution. The organic fraction can be accessed through the release of phosphatase enzymes [53] that aid in mineralization or by mycorrhizal uptake through organic root exudates [54], therefore rendering this pool accessible in the long term [54]. Only $\mathrm{P}_{\mathrm{o}}$ was found in any substantial quantity in the labile fraction, further indicating that mineralization and direct access of the organic $\mathrm{P}$ is of prime importance for both short-term and long-term availability. Primary mineral (Ca-based) P, extracted with $\mathrm{HCl}$, and 
residual $\mathrm{P}$, which is incorporated into other mineral structures, were not changed by fertilization. Therefore, fertilizer $P$, as expected by the early isotherm experiments [20], was quickly ( $<25$ years) processed through either the mineral or organic pathways and sorbed onto the abundant sesquioxides or converted to slowly mineralizable organic forms but hasn't yet become occluded or otherwise unavailable. This finding is similar to that found in many other long-term studies of $\mathrm{P}$ fractions in managed soils [54].

As previously suggested [15], additional $\mathrm{P}$ fertilization may be needed early in the next pine rotation for optimal short-term $\mathrm{P}$ availability. Phosphorus fertilization rates higher than $81 \mathrm{~kg} \mathrm{P} \mathrm{ha}^{-1}$ were less efficient, probably due to event-specific losses and long-term surface and subsurface lateral flow. However, the higher rates did result in Mehlich I extractable P greater than that normally considered deficient [3].

\section{Conclusions}

The implications of this study are three-fold. First, vegetation responded well to the lowest $\mathrm{P}$ fertilization rate in the absence of additional $\mathrm{N}$ fertilization, but did not respond to rates higher than $81 \mathrm{~kg} \mathrm{ha}^{-1}$ in the absence of $\mathrm{N}$ fertilization beyond that applied at establishment. Secondly, the majority of the fertilizer $\mathrm{P}$ found in the soil was contained in the moderately labile fraction, and may be slowly available to the next pine rotation. The organic $\mathrm{P}$ contained in the forest floor and decomposing roots will likely become labile as well [55]. Finally, although this soil had a very high $\mathrm{P}$ sorption capacity and low runoff potential, surface application of high rates of a relatively soluble $\mathrm{P}$ fertilizer was not an effective method for ensuring lasting P sufficiency beyond that of normal rates.

Therefore, high fertilization rates of soluble $\mathrm{P}$ fertilizer, intended to overcome the high $\mathrm{P}$ sorption capacity for optimal $\mathrm{P}$ uptake, are unwarranted given that they may not be more effective than lower rates (at least without concomitant $\mathrm{N}$ fertilizer applications) and they may contribute to eutrophication of water bodies and to the looming P crisis if $\mathrm{P}$ not retained in the soil [56]. Possible mitigations for ecosystem restoration activities that require high $\mathrm{P}$ fertilizer rates to achieve vegetative restoration goals include incorporation into the mineral soil, soil covering (mulch, cover crop, or natural vegetation) to reduce overland flow, application of a less soluble fertilizer, such as ground rock phosphate [57], or timing the fertilizer application better with respect to competition control [58].

\section{Acknowledgments}

The authors acknowledge the efforts of Allan Tiarks for installing the original study and Rick Stagg, Morris Smith, Michael Elliott-Smith, Jacob Floyd, and Alan Springer for technical help. Nancy Koerth provided invaluable statistical advice, and Mark Kimsey and Sheeja George provided comments on an earlier draft.

\section{Conflict of Interest}

The authors declare no conflict of interest. 


\section{References}

1. Cordell, D.; Drangert, J.-O.; White, S. The story of phosphorus: Global food security and food for thought. Glob. Environ. Change 2009, 19, 292-305.

2. Jokela, E.J. Nutrient Management of Southern Pines. In Slash Pine: Still Growing and Growing; Dickens, E.D., Barnett, J.P., Hubbard, W.G., Jokela, E.J., Eds.; General Technical Report SRS-6; USDA Forest Service, Southern Research Station: Asheville, NC, USA, 2004; pp. 27-35.

3. Wells, C.G.; Crutchfield, D.M.; Berenyi, N.M.; Davey, C.B. Soil and Foliar Guidelines for Phosphorus Fertilization of Loblolly pine; Research Paper SE-110; USDA Forest Service, Southeastern Forest Experiment Station: Asheville, NC, USA, 1973.

4. Allen, H.L.; Dougherty, P.M.; Campbell, R.G. Manipulation of water and nutrients-Practice and opportunity in southern U.S. pine forests. For. Ecol. Manag. 1990, 30, 437-453.

5. Gregoire, N.; Fisher, R.F. Nutritional diagnoses in loblolly pine (Pinus taeda L.) established stands using three different approaches. For. Ecol. Manag. 2004, 203, 195-208.

6. Albaugh, T.J.; Allen, H.L.; Fox, T.R. Historical patterns of forest fertilization in the southeastern United States from 1969 to 2004. South. J. Appl. For. 2007, 31, 129-137.

7. Scott, D.A.; Dean, T.J. Energy trade-offs between intensive biomass utilization, site productivity loss, and ameliorative treatments in Loblolly pine plantations. Biomass Bioenerg. 2006, 30, 1001-1010.

8. Scott, D.A.; Novosad, J.; Goldsmith, G. Ten-Year Results from the North American Long-Term Soil Productivity Study in the Western Gulf Coastal Plain. In Advancing the Fundamental Sciences: Proceedings of the Forest Service National Earth Sciences Conference, San Diego, CA, USA, 18-22 October 2004; Furniss, M., Clifton, C., Ronnenburg, K., Eds.; General Technical Report PNW-689; USDA Forest Service, Pacific Northwest Research Station: Portland, OR, USA, 2007; pp. 331-340.

9. Turner, J.; Lambert, M.J.; Humphreys, F.R. Continuing growth response to phosphate fertilizers by a Pinus radiata plantation over fifty years. For. Sci. 2002, 48, 556-568.

10. Ballard, R.; Fiskell, J.G.A. Phosphorus retention in the coastal plain forest soils: I. Relationship to soil properties. Soil Sci. Soc. Am. Proc. 1974, 38, 250-255.

11. Ballard, R.; Pritchett, W.L. Phosphorus retention in the coastal plain forest soils: II. Significance to forest fertilization. Soil Sci. Soc. Am. Proc. 1974, 38, 363-366.

12. Snowdon, P. Modeling Type 1 and Type 2 growth responses in plantations after application of fertilizer or other silvicultural treatments. For. Ecol. Manag. 2002, 163, 229-244.

13. Comerford, N.B.; McLeod, M.; Skinner, M. Phosphorus form and bioavailability in the pine rotation following fertilization. For. Ecol. Manag. 2002, 169, 203-211.

14. Gentle, S.W.; Humphreys, F.R.; Lambert, M.J. Continuing response on Pinus radiata to phosphatic fertilizers over two rotations. For. Sci. 1986, 32, 822-829.

15. Everett, C.J.; Palm-Leis, H. Availability of residual phosphorus fertilizer for Loblolly pine. For. Ecol. Manag. 2009, 258, 2207-2213.

16. Gentle, W.; Humphreys, F.R.; Lambert, M.J. An examination of a Pinus radiata phosphate fertilizer trial fifteen years after treatment. For. Sci. 1965, 11, 315-324. 
17. Fransson, A.-M.; Bergvist, B. Phosphorus fertilisation causes durable enhancement of phosphorus concentrations in forest soil. For. Ecol. Manag. 2000, 130, 69-76.

18. Torbert, J.L.; Burger, J.A. Long-term availability of applied phosphorus to Loblolly pine on a Piedmont soil. Soil Sci. Soc. Am. J. 1984, 48, 1174-1178.

19. Pritchett, W.L.; Comerford, N.B. Long-term response to phosphorus fertilization on selected southeastern coastal plain soils. Soil Sci. Soc. Am. J. 1982, 46, 640-644.

20. Tiarks, A.E. Phosphorus sorption curves for evaluating phosphorus requirements of Loblolly pine (Pinus taeda). Commun. Soil Sci. Plan. 1982, 13, 619-631.

21. Sheoran, V.; Sheoran, A.S.; Poonia, P. Soil reclamation of abandoned mine land by revegetation: A review. Int. J. Soil Sediment Water 2010, 3, Article 13. Available online: http://scholarworks. umass.edu/intljssw/vol3/iss2/13/ (accessed on 29 August 2012).

22. Gray, C.A.; Schwab, A.P. Phosphorus-fixing ability of high $\mathrm{pH}$, high calcium, coal-combustion, waste materials. Water Air Soil Poll. 1993, 69, 309-320.

23. Tiarks, A.E. Phosphorus Requirements for Establishment of Dual-Cropped Loblolly pine. In Proceedings of the Third Biennial Southern Silvicultural Research Conference, Atlanta, GA, USA, 7-8 November 1984; Shoulders, E., Ed.; General Technical Report SO-54; USDA Forest Service, Southern Forest Experiment Station: New Orleans, LA, USA, 1985; pp. 390-394.

24. Tiarks, A.E. Biomass production of Loblolly pine seeded between rows of planted Loblolly pine. Biomass Bioenerg. 1993, 4, 61-67.

25. Kerr, A., Jr.; Griffis, B.J.; Powell, J.W.; Edwards, J.P.; Venson, R.L.; Long, J.K.; Kilpatrick, W.W. Soil Survey of Rapides Parish, Louisiana; USDA Soil Conservation Service: Washington, DC, USA, 1980.

26. Scott, D.A.; Tiarks, A.E. Dual-cropping Loblolly pine for biomass energy and conventional wood products. South. J. Appl. For. 2008, 32, 33-37.

27. Baldwin, V.C., Jr.; Feduccia, D.P. Loblolly pine Growth and Yield Prediction for Managed West Gulf Plantations; Research Paper SO-236; USDA Forest Service, Southern Forest Experiment Station: New Orleans, LA, USA, 1987.

28. Scott, D.A.; Stagg, R.H.; Smith, M.A., Jr. A Non-Destructive Method for Quantifying Small-Diameter Woody Biomass in Southern Pine Forests. In Proceedings of the 13th Biennial Southern Silvicultural Research Conference, Memphis, TN, USA, 28 February-3 March 2005; Connor, K.F., Ed.; General Technical Report SRS-92; USDA Forest Service, Southern Research Station: Asheville, NC, USA, 2006; pp. 358.

29. Murphy, J.; Riley, J.P. A modified single solution method for the determination of phosphate in natural waters. Anal. Chim. Acta. 1962, 27, 31-36.

30. Gee, G.W.; Bauder, J.W. Particle-Size Analysis. In Methods of Soil Analysis, 2nd ed.; Klute, A., Ed.; Agronomy Monograph 9; American Society of Agronomy and Soil Science Society of America: Madison, WI, USA, 1986; Part 1, pp. 383-411.

31. Mehlich, A. Determination of $\mathrm{P}, \mathrm{Ca}, \mathrm{Mg}, \mathrm{K}, \mathrm{Na}$ and $\mathrm{NH}_{4}$; North Carolina Soil Testing Division Mimeo: Raleigh, NC, USA, 1953.

32. Tiessen, H.; Moir, J.O. Characterization of Available P by Sequential Extraction. In Soil Sampling and Methods of Analysis, 2nd ed.; Carter, M.R., Gregorich, E.G., Eds.; CRC Press: Boca Raton, FL, USA, 2007; pp. 293-306. 
33. Fox, T.R.; Comerford, N.B.; McFee, W.W. Phosphorus and aluminum release from a spodic horizon mediated by organic acids. Soil Sci. Soc. Am. J. 1990, 54, 1763-1767.

34. Thornthwaite, C.W. An approach toward a rational classification of climate. Geogr. Rev. 1948, 38, 55-94.

35. Conner, W.H.; Toliver, J.R.; Sklar, F.H. Natural regeneration of baldcypress (Taxodium distichum (L.) Rich.) in a Louisiana swamp. For. Ecol. Manag. 1986, 14, 305-317.

36. National Climatic Data Center. Available online: http://www.ncdc.noaa.gov/oa/ncdc.html (accessed on 20 August 2012).

37. SAS Institute. SAS/STAT Users Guide; SAS Institute, Inc.: Cary, NC, USA, 2004; pp. 2659-2851.

38. Fox, T.R.; Allen, H.L.; Albaugh, T.J.; Rubilar, R.; Carlson, C.A. Tree nutrition and forest fertilization of pine plantations in the southern United States. South. J. Appl. For. 2007, 31, 5-11.

39. Hynynen, J.; Burkhart, H.E.; Allen, H.L. Modeling tree growth in fertilized midrotation Loblolly pine plantations. For. Ecol. Manag. 1998, 107, 213-229.

40. Pote, D.H.; Daniel, T.C.; Sharpley, A.N.; Moore, P.A., Jr.; Edwards, D.R.; Nichols, D.J. Relating extractable soil phosphorus to phosphorus losses in runoff. Soil Sci. Soc. Am. J. 1996, 60, $855-859$.

41. Shepherd, M.A.; Withers, P.J. Phosphorus leaching from liquid digested sewage sludge applied to sandy soils. J. Agr. Sci. 2001, 136, 433-441.

42. Turtola, E.; Yli-Halla, M. Fate of phosphorus applied in slurry and mineral fertilizer: Accumulation in soil and release into surface runoff water. Nutr. Cycl. Agroecosys. 1999, 55, 165-174.

43. Shoulders, E.; Tiarks, A.E. Fertilizer fate in a 13-year-old slash pine plantation. Soil Sci. Soc. Am. J. 1980, 44, 1085-1089.

44. Djodjic, F.; Börling, K.; Bergström, L. Phosphorus leaching in relation to soil type and soil phosphorus content. J. Environ. Qual. 2004, 33, 678-684.

45. Fraser, A.I.; Harrod, T.R.; Haygarth, P.M. The effect of rainfall intensity on soil erosion and particulate phosphorus transfer from arable soils. Water Sci. Technol. 1999, 39, 41-45.

46. Nash, D.L.; Clemow, L.; Hannah, M.; Barlow, K.; Gangaiya, P. Modelling phosphorus exports from rain-fed and irrigated pastures in southern Australia. Aust. J. Soil Res. 2005, 43, 745-755.

47. Preedy, N.; McTiernan, K.; Matthews, R.; Heathwaite, L.; Haygarth, P. Rapid incidental phosphorus transfers from grassland. J. Environ. Qual. 2001, 30, 2105-2112.

48. Haygarth, P.M.; Jarvis, S.C. Transfer of phosphorus from agricultural soils. Adv. Agron. 1999, 66, 195-249.

49. Withers, P.J.A.; Ulen, B.; Stamm, C.; Bechmann, M. Incidental phosphorus losses-Are they significant and can they be predicted? J. Plant Nutr. Soil Sci. 2003, 166, 459-468.

50. Hart, M.R.; Quin, B.F.; Nguyen, M.L. Phosphorus runoff from agricultural land and direct fertilizer effects: A review. J. Environ. Qual. 2004, 33, 1954-1972.

51. Sharpley, A.N.; McDowell, R.W.; Kleinman, P.J.A. Phosphorus loss from land to water: Integrating agricultural and environmental management. Plant Soil 2004, 237, 287-307.

52. Kleinman, P.J.A.; Sharpley, A.N.; Moyer, B.G.; Elwinger, G.F. Effect of mineral and manure phosphorus sources on runoff phosphorus. J. Environ. Qual. 2002, 31, 2026-2033. 
53. Fox, T.R.; Comerford, N.B. Rhizosphere phosphatase activity and phosphatase hydrolyzable organic phosphorus in two forested spodosols. Soil Biol. Biochem. 1992, 24, 579-583.

54. Richter, D.D.; Allen, H.L.; Li, J.; Markewitz, D.; Raikes, J. Bioavailability of slowly cycling soil phosphorus: Major restructuring of soil $\mathrm{P}$ fractions over four decades in an aggrading forest. Oecologia 2006, 150, 259-271.

55. Polglase, P.J.; Jokela, E.J.; Comerford, N.B. Nitrogen and phosphorus release from decomposing needles of southern pine plantations. Soil Sci. Soc. Am. J. 1992, 56, 914-920.

56. Beardsley, T.M. Peak phosphorus. BioScience 2011, 61, 91.

57. McDowell, R.W.; Monaghan, R.M.; Carey, P.L. Potential phosphorus losses in overland flow from pastoral soils receiving long-term applications of either superphosphate or reactive phosphate rock. New Zeal. J. Agr. Res. 2003, 46, 329-337.

58. Haywood, J.D.; Tiarks, A.E.; Snow, G.A. Combinations of fungicide and cultural practices influence the incidence and impact of fusiform rust in slash pine plantations. South. J. Appl. For. 1994, 18, 53-59.

(C) 2012 by the authors; licensee MDPI, Basel, Switzerland. This article is an open access article distributed under the terms and conditions of the Creative Commons Attribution license (http://creativecommons.org/licenses/by/3.0/). 